Original Research Paper

\title{
PKM Pemanfaatan Sekam Padi Sebagai Alternatif Campuran Material Dinding Ringan untuk Mendukung Hunian Tahan Gempa di Kota Palu
}

\author{
I Gede Tunas $^{1 *}$, Asrafil ${ }^{2}$, Ni Made Suwitri Parwati ${ }^{3}$ \\ ${ }^{1}$ Jurusan Teknik Sipil, Fakultas Teknik, Universitas Tadulako, Palu, Indonesia; \\ ${ }^{2}$ Jurusan Teknik Geologi, Fakultas Teknik, Universitas Tadulako, Palu, Indonesia; \\ ${ }^{2}$ Jurusan Akuntansi, Fakultas Ekonomi, Universitas Tadulako, Palu, Indonesia.
}

https://doi.org/10.29303/jpmpi.v3i2.926

Sitasi: Tunas, I. G., Asrafil \& Parwati, N. M. S. (2021). PKM Pemanfaatan Sekam Padi Sebagai Alternatif Campuran Material Dinding Ringan untuk Mendukung Hunian Tahan Gempa di Kota Palu. Jurnal Pengabdian Magister Pendidikan IPA, 4(3)

\section{Article history}

Received: 28 Agustus 2021

Revised: 4 September 2021

Accepted: 6 September 2021

*Corresponding Author: I Gede Tunas, Jurusan Teknik Sipil Fakultas Teknik Universitas Tadulako, Palu, Indonesia; Email: tunasw@yahoo.com

\begin{abstract}
The involvement and empowerment of communities affected by the September 28, 2018 Palu Earthquake in their home areas is an opportunity that can be taken to contribute to residential reconstruction. Currently, the rehabilitation and construction of housing requires a lot of materials that support earthquake-resistant buildings, one of which is construction materials for the walls of houses or dwellings that have light weights such as light bricks, which are mostly supplied from outside the Central Sulawesi area. For this purpose, this paper presents the results of the implementation of the Community Partnership Program (PKM) in disaster-affected communities by utilizing rice husks as light brick materials. Implementation of the program begins with socialization to prospective participants and continues with the work and testing of light brick samples, training to make lightweight bricks, monitoring and evaluation. The test results show that light brick made of a mixture of cement, husk and sand (Type II) with a volume ratio of 1:1.5:4.5 still meets the requirements as a house wall material and it is included in Quality Level III (SNI 03-0349-1989). This type II brick is then recommended as a wall material, where this type provides a weight reduction of $54.85 \%$ from the weight of conventional bricks. A review of the results of program implementation shows that the affected communities represented by 50 respondents gave a fairly good perception of the acceptance of light bricks as wall material with a score of 3.70 of 5 . Evaluation of the program showed that $80 \%$ of all respondents stated that they were skilled at making light bricks. and they will develop these material to support the reconstruction of housing in Palu.
\end{abstract}

Keywords: Community Empowerment, Survivor, Light Brick, Reconstruction

pencaharian dan pekerjaan lebih dari 1000 Kepala Keluarga (KK) yang bermukim di hunian sementara yang tersebar di beberapa titik di Kelurahan Petobo, Kecamatan Palu Selatan Kota Palu Provinsi Sulawesi Tengah, dimana seluruh

2018 telah menyebabkan kehilangan sumber 
lahan dan bangunan pada area liquifaksi ini telah hancur (Tim Rehabilitasi Bencana, 2019). Hunian sementara ini terletak di ujung Timur Kelurahan Petobo dan berbatasan dengan Kabupaten Sigi berjarak kurang lebih $5 \mathrm{~km}$ ke arah selatan dari Pusat Kota Palu. Masyarakat yang bermukim di hunian sementara ini, semuanya adalah para penyintas yang berasal dari area Liquifaksi Petobo (SATGAS Penanggulangan Bencana, 2018). Area ini merupakan salah satu wilayah yang paling parah dampak kerusakannya sehingga ditetapkan sebagai zona merah dan dilarang untuk dibangun kembali sebagai tempat permukiman (Sagita dan Hariyati, 2019).

Sebagaian besar dari para penyintas adalah masyarakat yang tidak memiliki keterampilan atau berketerampilan rendah (Hutabarat dkk, 2019) untuk dapat diikutsertakan dalam rehabilitasi dan rekonstruksi Palu pasca bencana yang saat ini sementara berlangsung. Sebagaimana telah diketahui pada masa rekonstruksi Palu dan sekitarnya, dibutuhkan tenaga terampil dalam jumlah yang besar baik dalam proses pelaksanaan rekonstruksi maupun dalam proses penyiapan materialnya. Material konstruksi yang paling banyak dibutuhkan dalam masa rekonstruksi ini dalam material dinding tahan gempa berupa bata ringan. Masyarakat penyintas di Huntara Petobo sampai saat ini belum ada yang diketahui memiliki keterampilan untuk mencetak bata ringan. Untuk dapat berpartisipasi mengisi kesempatan tersebut, para penyintas harus diberi pengetahuan dan keterampilan untuk dapat direkrut menjadi tenaga kerja atau bisa membuka uasaha sendiri. Pengetahuan dan keterampilan yang akan diberikan ini diharapkan dapat meningkatkan kemandirian dan bisa lepas dari ketergantungan bantuan pemerintah selama berada di huntara (Masikome, 2018; Bahransyaf, 2020; Maulidia, 2020) atau bila mereka sudah direlokasi ke hunian tetap (huntap).

Salah satu bahan dasar yang dapat digunakan sebagai material bata ringan adalah abu sekam padi (Budirahardjo, dkk, 2014; Abidin dkk, 2018). Abu ini merupakan produk dari pembakaran sekam padi dengan suhu tertentu yang dapat dipakai dalam campuran bata. Abu sekam padi dapat menghasilkan kekuatan beton yang tinggi, dengan berkurangnya porositas bata, dan tentunya produk ini lebih ramah terhadap lingkungan (Pratama dkk, 2014). Sekam padi mempunyai kandungan silika sebanyak 94-96\%, dengan
Pozzolanic Activity Index mencapai 87\% (Paresa dan Hairulla, 2015).

Berdasarkan hal tersebut, Program Kemitraan Masyarakat (PKM) ini bermaksud memanfaatkan abu sekam padi sebagai bahan dasar bata ringan yang akan digunakan sebagai material dinding hunian tahan gempa di Kota Palu dalam rangka rekonstruksi. Untuk memproduksi bata jenis ini, para penyintas diberikan pengetahuan dan keterampilan dalam menyiapkan komposisi bahan, mencetak, merawat dan memasarkannya. Target akhir dari PKM ini adalah menyiapkan wirausaha mandiri (Widowati dan Sinaga, 2016) melalui penyiapan bata ringan sebagai material dinding hunian tahan gempa menggunakan abu sekam padi sebagai bahan dasar.

\section{Metode}

Metode yang diterapkan pada PKM dalam rangka menyiapkan tenaga terampil dan memproduksi bata ringan dari abu sekam padi adalah: persiapan, sosialisasi, penyiapan bahan dan peralatan, pembuatan dan pengujian benda uji, pelatihan pembuatan bata ringan, monitoring dan evaluasi.

\section{Persiapan}

Persiapan PKM dilakukan untuk konsolidasi tim, menyusun rencana kerja, mempersiapkan bahan dan peralatan PKM, koordinasi dengan mitra.

\section{Sosialisasi PKM}

Sosialisasi kegiatan PKM dilakukan untuk menginformasikan rencana kegiatan PKM secara langsung kepada seluruh anggota mitra. Sosialisasi dilakukan di Kantor Kelurahan Petobo bagi masyarakat di huntara. Sosialisasi dilanjutkan dengan perekrutan peserta pelatihan terutama untuk masyarakat usia produktif sebanyak 20 orang. Pada tahap ini juga dilakukan pengisian kuisioner kepada mitra (responden) untuk mengukur tingkat pengetahuan dan penerimaan terhadap bata ringan.

\section{Pembuatan dan Pengujian Benda Uji}

Benda uji bata ringan dibuat dalam 3 tipe, seperti pada Tabel 1. Pembuatan benda uji menggunakan bahan dan alat seperti: semen, pasir, abu sekam, air, cetakan bata, sekop, tenda, dan peralatan/bahan lainnya. Setelah berumur 28 hari, 
pengujian kuat tekan diterapkan (Syahrun dkk, 2019) pada ketiga tipe benda uji tersebut untuk mengetahui kinerja ketiga tipe bata tersebut sebagai material dinding.

\section{Tabel 1 Komposisi campuran bata ringan}

\begin{tabular}{cccc}
\hline Bahan & \multicolumn{3}{c}{ Benda Uji } \\
\cline { 2 - 4 } (volume) & Tipe I & Tipe II & Tipe III \\
\hline Semen & 1 & 1 & 1 \\
\hline Pasir & 3 & 1.5 & 0 \\
\hline Sekam & 3 & 4.5 & 6 \\
\hline
\end{tabular}

\section{Pelatihan Pembuatan Bata Ringan}

Pada tahap ini akan didemonstrasikan kepada peserta dan dipraktekkan oleh peserta mulai dari mempersiapkan bahan, menyiapkan komposisi campuran, cara mencampur bahan, cara mencetak bata dan cara merawatnya pasca cetak sampai siap didistribusikan. Kegiatan pelatihan ini diberikan oleh para instruktur terlatih, terampil dan berpengalaman

\section{Monitoring dan Evaluasi}

Monitoring dan evaluasi ini dilakukan untuk menilai apakah kegiatan PKM yang telah dilakukan sudah mencapai target sesuai proposal yang diajukan (Subiyantoro, 2010; Sulistyowati dan Ekawat, 2021). Temuan-temuan baru selama melaksanakan PKM akan menjadi bahan baru untuk diajukan pada kegiatan PKM selanjutnya.

\section{Hasil dan Pembahasan}

\section{Sosialisai PKM}

Sosialisasi Pelaksanaan PKM dilaksanakan pada tanggal 7 Mei 2021 di Kelurahan Petobo (Gambar 1) dengan melibatkan mahasiswa Jurusan Teknik Sipil Universitas Tadulako (Gambar 2). Sosialisasi rencana kegiatan PKM dilakukan untuk menginformasikan rencana kegiatan PKM secara langsung kepada seluruh anggota mitra di Kantor Kelurahan Petobo. Sosialisasi kegiatan di buka oleh Lurah Petobo dan dihadiri oleh peserta dan staf kelurahan, didahului dengan penyampaian maksud dan tujuan kegiatan oleh Tim PKM. Pada tahap ini juga diberikan pengarahan oleh Lurah Petobo kepada para peserta sosialisasi agar mengikuti kegiatan dengan baik karena berpeluang untuk menjadi wira usaha bata ringan.
Selanjutnya acara sosialisasi diisi dengan pengisian kuisioner oleh para peserta. Kuisioner ini bertujuan untuk menilai persepsi masyarakat (responden) (Tika dkk, 2017; Muthia, 2020) tentang pengenalan dan penerimaan bata ringan sebagai material konstruksi. Jumlah pertanyaan dalam kuisioner adalah 10 butir berupa pilihan sesuai dengan pemahaman responden. Kuisioner ini juga berfungsi untuk mengukur persepsi dan penerimaan masyarakat untuk pengembangan bata ringan dalam rangka rekonstruksi hunian pasca Gempa Palu 2018 .

Kegiatan sosialisasi ini berhasil dilaksanakan dengan baik dan mendapat tanggapan posistif dari seluruh peserta sosialisasi. Kegiatan sosialisasi ini selain didokumentasikan dalam bentuk video kegiatan, juga telah terpubikasi pada Harian Mercusuar.

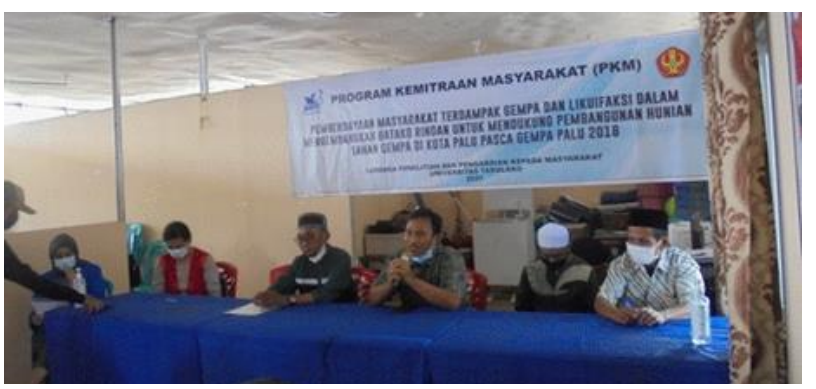

Gambar 1 Sosialiasi PKM

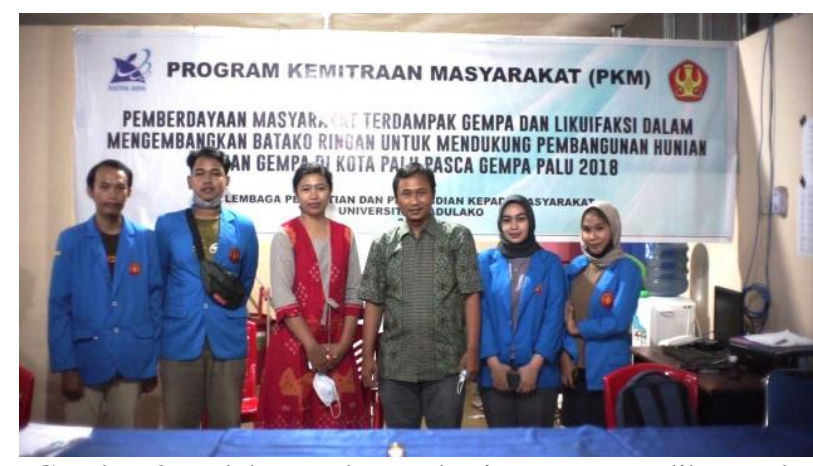

Gambar 2 Pelaksana dan mahasiswa yang terlibat pada sosialiasi PKM

\section{Pembuatan dan Pengujian Benda Uji}

Bata ringan terbuat dari campuran sekam, semen, pasir, dan air. Campuran bata terkomposisi dari perbandingan berat dengan 4 (empat) tipe seperti pada Tabel 1. Keempat tipe ini digunakan untuk mendapatkan berat bata dan kuat tekan optimal. Hal ini berarti bahwa tipe bata yang diinginkan mempunyai bobot seringan-ringannya dan kuat tekan setinggi-tingginya (Tanjung dan Munte, 2020). 


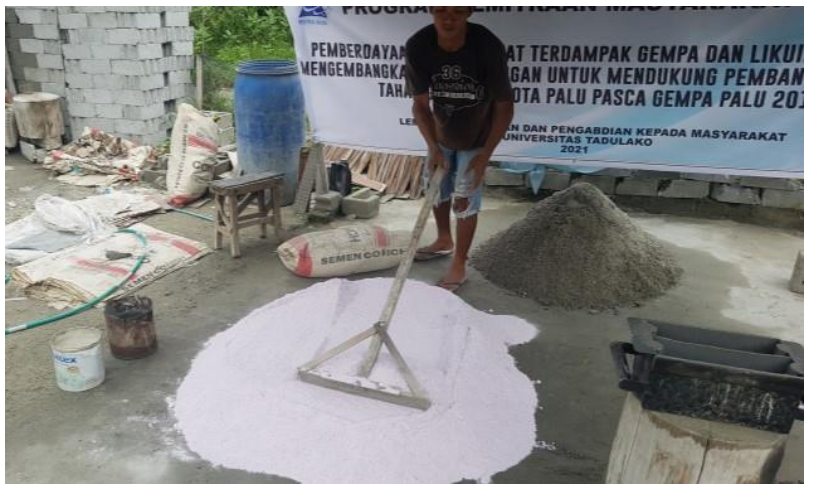

Gambar 3 Pencampuran bahan

Pembuatan benda uji diawali dengan penyiapan bahan campuran untuk masing-masing tipe dan selanjutnya dilakukan pencampuran material sampai merata (Gambar 3). Bahan yang sudah tercampur merata, diberikan air pencampur secara perlahan dengan jumlah tertentu, sehingga campuran tidak terlalu encer dan tidak terlalu padat. Proses ini dilakukan secara berulang sampai diperoleh campuran yang siap untuk dicetak. Pencetakan bata dilakukan menggunakan alat pencetak standar didahului dengan pemadatan campuran pada cetakan.

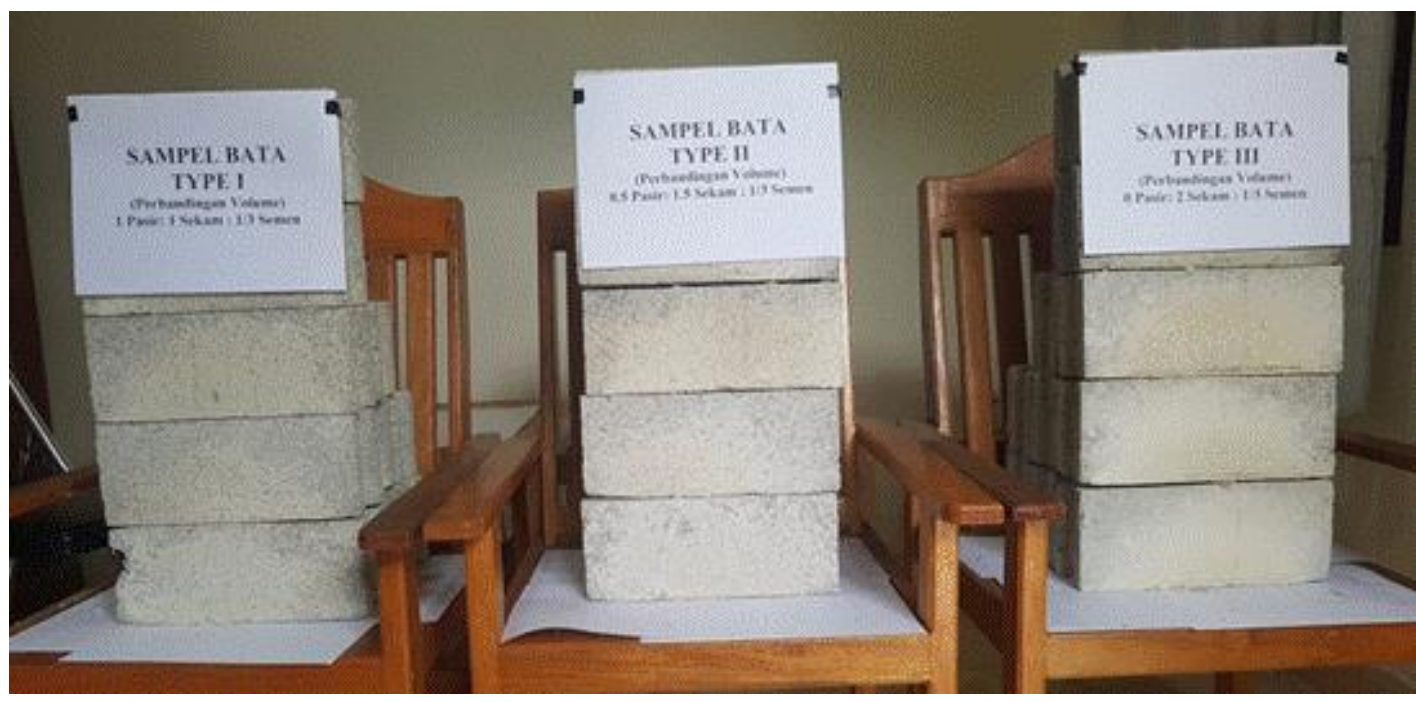

Gambar 4 Benda uji

Tabel 2 Karakteristik sampel bata ringan dan bata konvensional (benda uji)

\begin{tabular}{|c|c|c|c|c|}
\hline \multirow{2}{*}{ Karakteristik } & \multicolumn{4}{|c|}{ Benda Uji/Sampel } \\
\hline & Tipe I & Tipe II & Tipe III & Tipe IV \\
\hline Berat $1(\mathrm{~kg})$ & 3.6 & 2.95 & 1.45 & 5.4 \\
\hline Berat II $(\mathrm{kg})$ & 3.8 & 3.2 & 1.6 & 5.6 \\
\hline Berat III $(\mathrm{kg})$ & 3.7 & 2.9 & 1.5 & 5.5 \\
\hline Berat rerata $(\mathrm{kg})$ & 3.70 & $\mathbf{3 . 0 2}$ & 1.52 & 5.50 \\
\hline Panjang (m) & 0.29 & 0.29 & 0.29 & 0.29 \\
\hline Lebar (m) & 0.09 & 0.09 & 0.09 & 0.09 \\
\hline Tinggi (m) & 0.12 & 0.12 & 0.12 & 0.12 \\
\hline Volume bruto $\left(\mathrm{m}^{3}\right)$ & 0.0031 & 0.0031 & 0.0031 & 0.0031 \\
\hline Volume netto $\left(\mathrm{m}^{3}\right)$ & 0.0027 & 0.0027 & 0.0027 & 0.0027 \\
\hline Berat volume $\mathrm{kg} / \mathrm{m}^{3}$ ) & 1357.73 & 1106.98 & 556.55 & 2018.25 \\
\hline $\begin{array}{l}\text { Persentase berat volume } \\
\text { terhadap bata konvensioanl (\%) }\end{array}$ & 67.27 & 54.85 & 27.58 & 100 \\
\hline Warna & $\begin{array}{c}\text { Abu-abu putih } \\
\text { level } 1 \text { (cerah } \\
50 \%)\end{array}$ & $\begin{array}{c}\text { Abu-abu putih } \\
\text { level } 2 \text { (cerah } \\
75 \%)\end{array}$ & $\begin{array}{c}\text { Abu-abu putih } \\
\text { level } 3 \text { (cerah } \\
100 \%)\end{array}$ & $\begin{array}{l}\text { Hitam keabu- } \\
\text { abuan }\end{array}$ \\
\hline
\end{tabular}


Pemeliharaan sampel bata ringan dilakukan setelah bata tercetak. Penyiraman secara berkala setiap hari selama 28 hari merupakan bentuk utama pemeliharan bata yang sudah tercetak. Penyiraman bata dilakukan pada pagi dan sore hari dimana pada saat ini kadar atau kandungan air pada bata sudah berkurang akibat pengembunan di malam hari dan penguapan di siang hari. Penyiraman ini ditujukan untuk menjamin pengerasan bata terjadi secara normal dan secara berangsur. Dengan perlakuan ini diharapkan bata akan mengeras secara optimal sehingga kekuatannya maksimal (Paresa dan Hairulla, 2015).

Pengujian kekuatan tekan bata ringan dilakukan terhadap 3 sampel bata ringan (Tipe I, Tipe II dan Tipe III) dan 1 sampel bata konvensional (Tipe IV). Sampel bata ringan Tipe IIII disajikan pada Gambar 4. Sebelum dilaksanakan pengujian sampel, dilakukan pengukuran karakteristik bata ringan dan bata konvensional berupa dimensi (ukuran), berat sampel dan berat volume. Tabel 2 menyajikan karakteristik sampel/benda uji, dimana pengukuran berat diterapkan pada 3 benda uji/sampel pada masingmasing tipe.

Sebagaimana tampak pada Tabel 2, perbedaan nyata dari keempat tipe sampel, yang pertama adalah dari segi warna. Bata konvensional, umumnya berwarna hitam keabu-abuan, dan warnanya juga tergantung dari jenis pasir dan semen yang digunakan. Namun secara umum untuk pasir di Sulawesi Tengah khususnya Palu, bata tanpa campuran sekam menghasilkan warna dominan hitam keabu-abuan. Warna bata akan berubah semakin cerah (putih) seiring dengan meningkatnya kadar sekam pada bata. Bata Tipe III menghasilkan warna yang paling cerah sehubungan dengan bahan bata ini hanya menggunakan semen dan sekam tanpa campuran pasir.

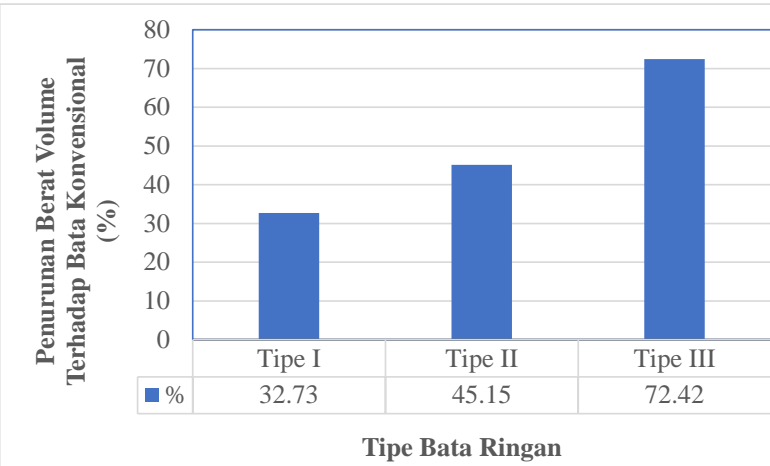

Gambar 5 Penurunan berat volume bata ringan terhadap bata konvensional

Dari segi berat volume, rata-rata bata konvensional menghasilkan berat volume 2000$2200 \mathrm{~kg} / \mathrm{m}^{3}$, bergantung dari jenis pasir yang digunakan sebagai material campuran bata. Pada sampel ini, Bata Tipe IV memberikan berat volume rata-rata sebesar $2018.25 \mathrm{~kg} / \mathrm{m}^{3}$. Berat volume bata berkurang dengan menurunnya kadar pasir dan meningkatnya kadar sekam pada campuran. Pada bata Tipe I, terjadi penurunan berat volume sebesar $32.73 \%$, pada bata Tipe II berat volume turun $45.15 \%$ dan pada bata Tipe III penurunan volume mencapa 72.42\% (Gambar 5). Hal ini menunjukkan bahwa penambahan sekam pada campuran secara signifikan dapat menurunkan berat volume bata. Namun demikian komposisi campuran ideal dari sekam terhadap bata dapat ditetapkan berdasarkan hasil uji kuat tekan.

Tabel 3 Hasil uji kuat tekan sampel bata ringan dan konvensional

\begin{tabular}{lcccc}
\hline \multirow{2}{*}{ Kuat Tekan } & \multicolumn{4}{c}{ Benda Uji/Sampel } \\
\cline { 2 - 5 } & Tipe I & Tipe II & Tipe III & Tipe IV \\
\hline Pengujian 1 $\left(\mathrm{kg} / \mathrm{cm}^{2}\right)$ & 45.6 & 34.8 & 22.5 & 65.5 \\
Pengujian 2 $\left(\mathrm{kg} / \mathrm{cm}^{2}\right)$ & 47.2 & 36.4 & 19.6 & 63.6 \\
Pengujian 3 $\left(\mathrm{kg} / \mathrm{cm}^{2}\right)$ & 42.5 & 36.8 & 21.4 & 63.8 \\
Rata-rata $\left(\mathrm{kg} / \mathrm{cm}^{2}\right)$ & $\mathbf{4 5 . 1 0}$ & $\mathbf{3 6 . 0 0}$ & $\mathbf{2 1 . 1 7}$ & $\mathbf{6 4 . 3 0}$ \\
Pengujian 1 $(\mathrm{MPa})$ & 4.47 & 3.41 & 2.21 & 6.42 \\
Pengujian 2 $(\mathrm{MPa})$ & 4.63 & 3.57 & 1.92 & 6.24 \\
Pengujian 3 $(\mathrm{MPa})$ & 4.17 & 3.61 & 2.10 & 6.26 \\
Rata-rata $(\mathrm{MPa})$ & $\mathbf{4 . 4 2}$ & $\mathbf{3 . 5 3}$ & $\mathbf{2 . 0 8}$ & $\mathbf{6 . 3 1}$ \\
\hline \multicolumn{1}{c}{ Tingkat Mutu } & III & III & IV & II \\
\hline
\end{tabular}

Berdasarkan hasil pengujian berat volume, ketiga tipe bata termasuk dalam kategori bata sangat ringan, dimana berat isi kurang dari 1360 $\mathrm{kg} / \mathrm{m}^{3}$. Menurut Murdock (1986, dalam Sumaryanto dkk, 2009), bata/beton ringan barada pada berat volume $1360-1840 \mathrm{~kg} / \mathrm{m}^{3}$ dengan kuat tekan 2,25 - 
12,11 MPa (Sumaryanto dkk, 2009). Tabel 3 menyajikan hasil uji kuat tekan sampel bata ringan dan konvensional.

Sesuai dengan peruntukannya, bata ringan ini akan digunakan sebagai dinding hunian pasca gempa dimana tidak untuk memikul beban dan digunakan untuk dinding non stuktural tak terlindungi boleh terkena hujan dan panas (Kelas Mutu III). Oleh karena itu sampel bata ringan yang memenuhi syarat untuk itu adalah Tipe I dan Tipe II. Namun mengingat bahwa Tipe II mempunyai bobot lebih ringan dari Tipe I, maka yang akan direkomendasikan adalah Bata Ringan Tipe II dengan komposisi campuran 1 Semen: 1.5 Pasir : 4.5 Sekam (volume) dengan berat volume rata-rata $=1106.98 \mathrm{~kg} / \mathrm{m}^{3}$.

\section{Pelatihan Pembuatan Bata Ringan}

Pelatihan pembuatan bata ringan dilakukan terhadap peserta yang memenuhi syarat sebagaimana yang dimaksud dalam kuisioner, yakni yang memiliki peminatan tinggi terhadap bata ringan, berkeinginan mengembangkan produk ini dan berniat menjadi wirausaha mandiri setelah mengikuti kegiatan PKM ini. Peserta pelatihan ini berjumlah 20 orang dan semuanya mendapat rekomendasi dari Lembaga Pemberdayaan Masyarakat (LPM) Kelurahan Petobo dimana kegiatan ini dilaksanakan.

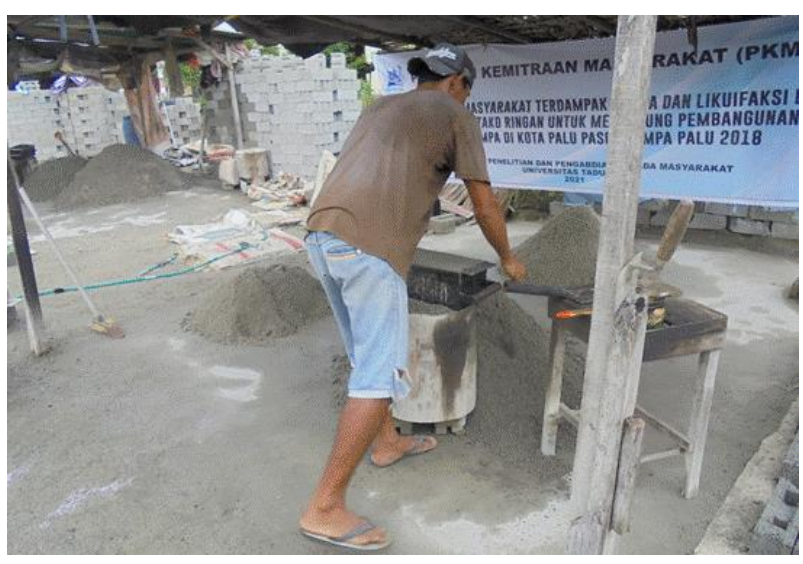

Gambar 6 Pelatihan pembuatan bata ringan

Pelatihan diawali dengan penyampaian materi oleh instruktur tentang pengetahuan bata ringan, jenis-jenis bata ringan, material bata ringan, dan materi yang terpenting adalah proses dan tatacara mencetak bata ringan. Bata ringan yang dibuat pada pelatihan ini adalah Bata Ringan Tipe II dengan komposisi volume 1 semen : 1.5 pasir :
$4.5 \mathrm{abu}$ sekam dengan berat volume rata-rata $1106.98 \mathrm{~kg} / \mathrm{m}^{3}$.

Setiap peserta diberikan kesempatan untuk membuat campuran sendiri dengan pemantauan dan pendampingan dari instruktur sesuai dengan komposisi campuran yang disyaratkan (Gambar 6). Sejumlah air diberikan secara bertahap dan merata, sampai campuran benar-benar siap untuk dicetak. Selanjutnya, setiap peserta diberi kesempatan untuk mencetak 3 buah bata ringan atau sampai peserta benar-benar dapat melakukan pencetakan dengan baik. Pada tahap ini peserta juga dapat berkonsultasi dengan instruktur bila ada permasalahan dalam proses pencetakan. Bata ringan yang sudah tercetak pada pelatihan ini dapat dilihat pada Gambar 7.

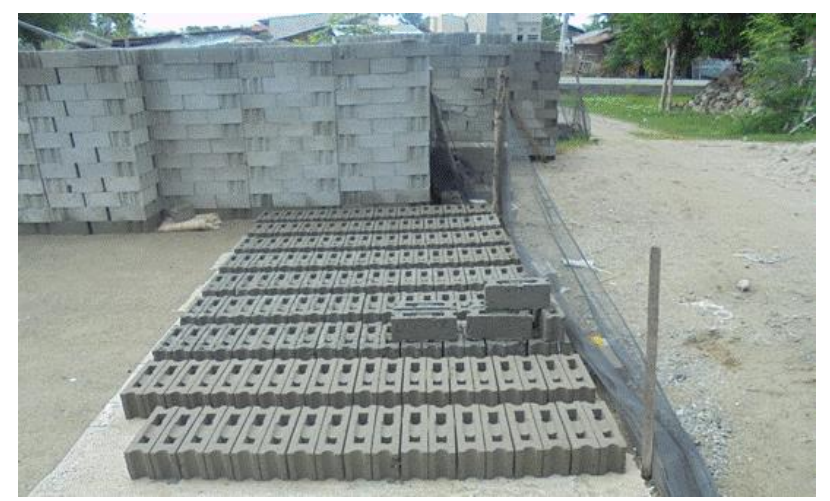

Gambar 7 Bata ringan yang sudah tercetak

\section{Monitoring dan Evaluasi}

Monitoring dan evaluasi ini dilakukan untuk menilai apakah kegiatan PKM yang telah dilakukan sudah mencapai target sesuai proposal yang diajukan. Bagian ini merupakan tahapan penting dalam setiap kegiatan. Temuan-temuan baru selama melaksanakan PKM akan menjadi bahan baru untuk diajukan pada kegiatan PKM selanjutnya.

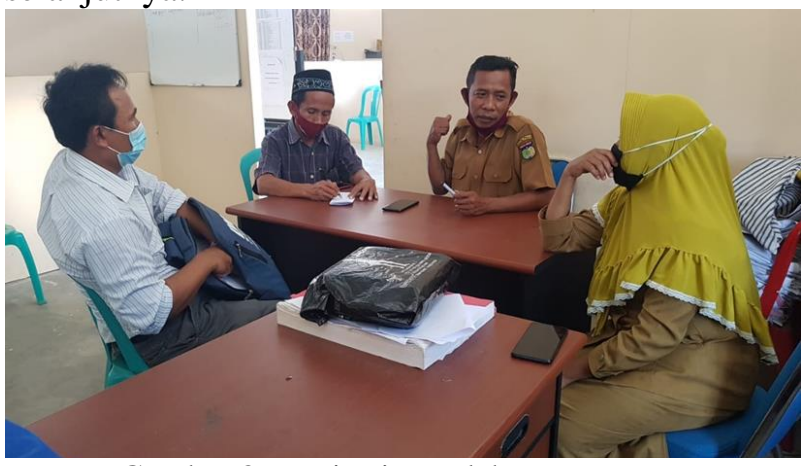

Gambar 8 Monitoring pelaksanaan PKM 
Monitoring dilaksanakan terhadap seluruh kegiatan PKM dengan berkoordinasi dengan pihak Kelurahan Petobo (Gambar 8) selaku institusi yang menaungi wilayah dimana PKM dilaksanakan.
Aktivitas peserta pelatihan juga dipantau setelah diberikan pengetahuan melalui pelatihan sebelumnya.

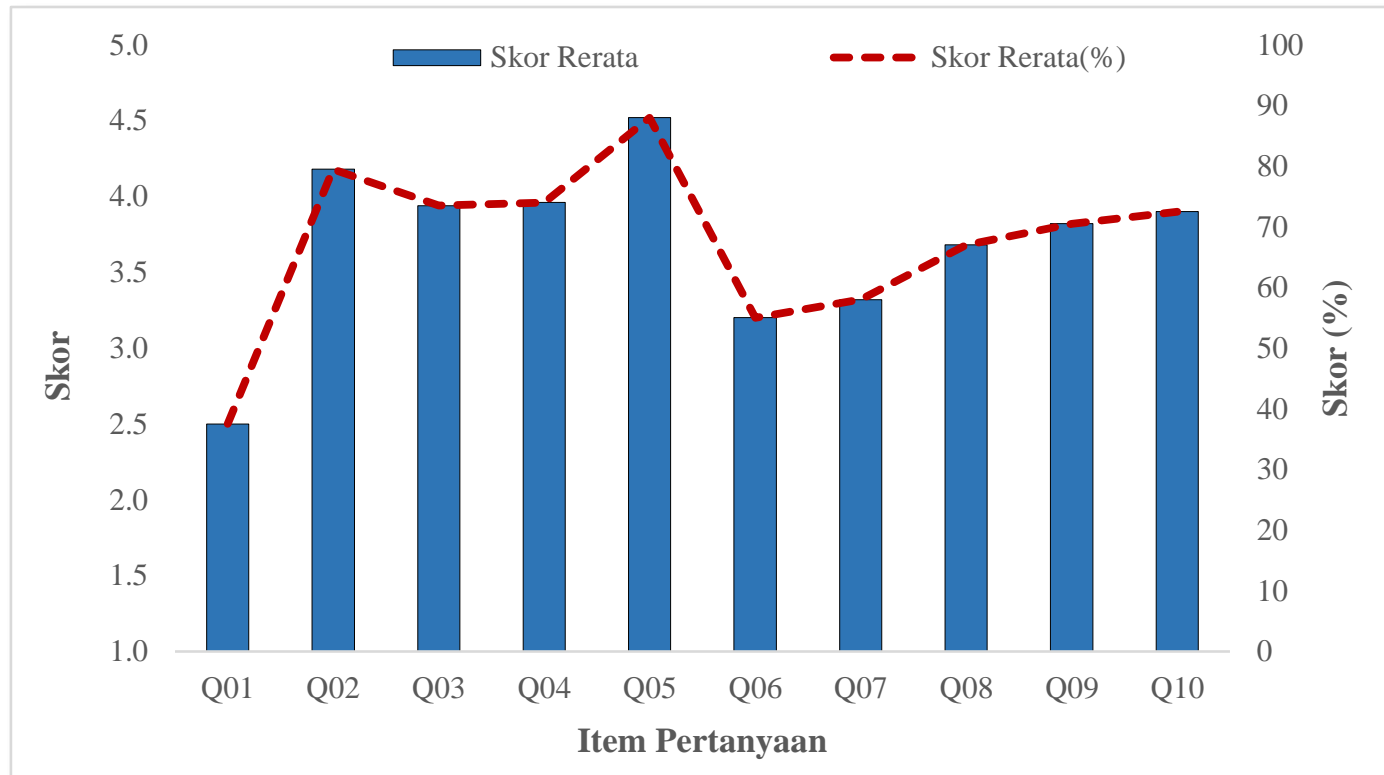

Gambar 9 Skor rata-rata dari sepuluh item pertanyaan pada 50 responden

Evaluasi kegiatan PKM dilakukan 2 tahapan yakni penilaian persepsi calon peserta (responden) sebanyak 50 orang dan penilaian penguasaan keterampilan membuat bata ringan terhadap peserta pelatihan sebanyak 20 orang. Evaluasi ini dilaksanakan sebelum dan setelah pelatihan pembuatan bata ringan. Penilaian persepsi para responden terhadap pengenalan, penerimaan dan peminatan bata ringan sebagai material konstruksi memberikan respon yang cukup baik. Para responden memberikan skor rata-rata 3.70 dari skor total 5 (Gambar 9). Hal ini menunjukkan bahwa tingkat persepsi para responden cukup baik baik dalam penerimaan maupun dalam pengembangan bata ringan sebagai material konstruksi, walaupun dengan pengenalan yang sangat terbatas.

Selanjutnya evaluasi terhadap penguasaan keterampilan terhadap 20 orang dengan memberikan kuisioner juga memberikan hasil yang sangat baik setelah mengikuti pelatihan. Enam belas peserta dari 20 orang yang dievaluasi menyatakan telah memiliki penguasaan yang baik dalam membuat bata ringan sesuai dengan komposisi campuran yang direkomendasikan. Verifikasi lapangan juga telah dilakukan untuk memvalidasi hasil penilaian kuisioner. Verifikasi dilakukan dengan cara menanyakan kembali proses pembuatan bata ringan dari penyiapan bahan dan peralatan sampai pemeliharaan bata ringan. Berdasarkan kedua jenis evaluasi tersebut, dapat dinyatakan bahwa PKM ini telah mencapai target sesuai dengan perumusan dan perancangan awal.

\section{Kesimpulan}

Kegiatan PKM telah dilaksanakan terhadap 20 orang peserta dari sejumlah masyarakat terdampak Gempa Palu 28 September 2018 di Kelurahan Petobo. PKM ini dilakukan dengan memberikan pengetahuan dan keterampilan pemanfaatan sekam padi sebagai material dinding untuk mensuplai kebutuhan rekonstruksi hunian tahan gempa di Kota Palu. Sekam padi dengan produksi melimpah di sekitar wilayah PKM, dirancang sebagai alternatif campuran bata untuk mendapatkan bobot material yang lebih ringan. Pelaksanaan program diawali dengan sosialisasi kepada calon peserta dan dilanjutkan dengan pengerjaan dan pengujian sampel bata ringan, pelatihan pembuatan bata ringan, monitoring dan evaluasi. Hasil pengujian menunjukkan bahwa bata 
ringan yang terbuat dari campuran semen, sekam dan pasir (Tipe II) dengan perbandingan volume 1:1.5:4.5 masih memenuhi syarat sebagai bahan dinding rumah dan termasuk dalam Tingkat Mutu III (SNI 03-0349-1989) (Juliafad dkk, 2019) untuk penggunaan dinding non-struktural tanpa pelindung, dapat terkena hujan dan panas dengan kuat tekan rata-rata $35 \mathrm{~kg} / \mathrm{cm}^{2}$. Bata Tipe II ini kemudian direkomendasikan sebagai material dinding, dimana tipe ini memberikan pengurangan berat sebesar $54.85 \%$ dari berat bata konvensional. Tinjauan terhadap hasil pelaksanaan program menunjukkan bahwa masyarakat terdampak yang diwakili oleh 50 responden memberikan persepsi yang cukup baik tentang penerimaan bata ringan sebagai bahan dinding dengan skor 3.70 dari 5 . Evaluasi program menunjukkan bahwa $80 \%$ dari seluruh responden menyatakan bahwa mereka terampil membuat batu bata ringan. dan mereka akan mengembangkan materi ini untuk mendukung rekonstruksi hunian di Palu.

\section{Saran}

Sejak Bulan Juli 2021, di Kota Palu dan sekitarnya diterapkan Program Pembatasan Kegiatan Masyarakat (PPKM) Level IV akibat meingkatnya angka penyebaran COVID-19. Pada kurun penerapan PPKM ini, kegiatan-kegiatan yang berkaitan dengan pertemuan langsung dengan tim dan peserta tidak bisa dilaksanakan sehingga harus ditunda pada bulan berikutnya. Oleh karena itu berpotensi capaian kegiatan tidak sesuai dengan yang diharapkan dan tim menyarankan untuk dipertimbangkan perpanjangan waktu pelaksanaan PKM.

\section{Ucapan Terima Kasih}

Penulis menghaturkan terima kasih yang setinggi-tingginya kepada Direktorat Riset dan Pengabdian Masyarakat, Direktorat Jenderal Penguatan Riset dan Pengembangan Kementerian Riset, Teknologi dan Pendidikan Tinggi atas dukungan dana yang telah diberikan melalui Skema Program Kemitraan Masyarakat dengan Kontrak Nomor: 078/SP2H/PPM/DRPM/2021.

\section{Daftar Pustaka}

Abidin, Z., Sunardi, S., dan Violet, V. (2018). Bata ringan dari campuran limbah sekam padi dan serbuk gergajian. Jurnal Pengabdian AlIkhlas, 3(2), 106-112.

Bahransyaf, D. (2020). Pemberdayaan masyarakat pasca bencana berbasis penelitian. Sosio Konsepsia, 9 (3), 47-56.

Budirahardjo, S., Kristiawan, A., dan Wardani, A. (2014). Pemanfaatan sekam padi pada batako. Prosiding Seminar Nasional Sains dan Teknologi, 1(1), 1-12.

Hutabarat, L.E., Simanjuntak, P., dan Tampubolon, S. (2019). Peningkatan kesadaran masyarakat terhadap kerusakan bangunan dan lingkungan pasca gempa, tsunami dan likuifaksi di Palu Sulawesi Tengah. Jurna Comunita Servizio, 1(2), 208-222.

Juliafad, S., Arifin, A.S.R.A., dan Putri, P.Y. (2019). Pelatihan pembuatan batako sesuai standar nasional indonesia untuk pemuda putus sekolah. Journal of Civil Engineering and Vocational Education, 6(4), 1-6.

Masikome, J.H.J, Lengkong, F.D.J., dan Londa, F.Y. (2018). Pemberdayaan masyarakat korban bencana banjir di Kota Manado. Jurnal Administrasi Publik, 4(65), 1-9.

Maulidia, W., Fadhilah, H.A., dan Hamid, H. (2020). Pemberdayaan perajin industri rotan pasca bencana oleh Dinas Perdagangan dan Perindustrian Kota Palu. Jurnal Pembangunan Pemberdayaan Pemerintahan, 5(1), 19-32.

Muthia, R., Mailani, F., dan Huriani, E. (2020). Pemberdayaan masyarakat melalui pelatihan mitigasi dan kesiapsiagaan bencana di Nagari Pakan Sinayan. Warta Pengabdian Andalas, 27(3), 187-196.

Paresa, J. dan Hairulla, H. (2015). Perlakuan campuran batako dengan menggunakan abu sekam padi sebagai bahan aditif. Jurnal Ilmiah Mustek Anim Ha, 4(3), 264-272.

Pratama, A., Karo, P.K., dan Sembiring, S. (2014). Pembuatan dan karakterisasi komposit batako ringan dengan campuran sekam padi sebagai bahan pengisi untuk kontruksi bangunan redam suara. Jurnal Teori dan Aplikasi Fisika, 2(1), 49-57.

Sagita, D.D. dan Hariyati, T. (2019). Pendampingan psikososial anak dan remaja 
pasca bencana di Palu, Sulawesi Tengah. Prosiding Abdimasmu, 1(1), 1-8.

SATGAS Penanggulangan Bencana (2018). Laporan Harian Kejadian Bencana, Pusat Komando Gabungan SATGAS Penanggulangan Bencana. Palu: Kementerian Pekerjaan Umum dan Perumahan Rakyat.

Subiyantoro, I. (2010). Upaya mengantisipasi bencana melalui kekuatan berbasiskan masyarakat. Jurnal Dialog Penanggulangan Bencana, 1(2), 55-62.

Sulistyowati, S. dan Ekawat, J. (2021). Pemberdayaan masyarakat menuju desa tangguh bencana di area terdampak bencana lumpur Lapindo, Sidoarjo. Relasi: Jurnal Ekonomi, 17(1), 181-201.

Sumaryanto, D., Satyarno, I., dan Tjokrodimulyo, K. (2009), Batako sekam padi komposit mortar semen. Forum Teknik Sipil, 19 (1), 1009-1020.

Syahrun, S., Ahzan S., dan Pangga, D. (2019). Uji tekan batako ringan dari limbah pengolahan emas dengan variasi komposisi abu sekam padi. Jurnal Penelitian dan Pengkajian Ilmu Pendidikan: e-Saintika, 2(2), 120-126.
Tanjung, D.A., dan Munte, S. (2020). pelatihan pembuatan bata ringan kepada home industri batu bata konvensional guna mendukung program pemerintah 1 juta rumah bersubsidi. Journal of Education, Humaniora and Social Sciences (JEHSS), 2(3), 187-196.

Tika, I.N., Agustiana, I.G.A.T., dan Erawan, D.A.W. (2017), Pengolahan limbah serbuk gergaji kayu menjadi bata akustik. Prosiding Seminar Nasional Pengabdian Kepada Masyarakat 2017, 585-593, Jakarta: Universitas Mercu Buana.

Tim Rehabilitasi Bencana (2019). Penyiapan Hunian Tetap (HUNTAP) Masyarakat Terdampak Gempa dan Liquifaksi 2018 di Kelurahan Petobo. Palu: Badan Penanggulangan Bencana Daerah (BPBD) Provinsi Sulawesi Tengah.

Widowati dan Sinaga, A. (2016). Studi kelayakan usaha pembuatan bata merah berbahan baku sedimen Bendungan Sengguruh. Jurnal Akses Pengabdian Indonesia, 1(1), 43-54. 